\title{
Glaciers and climate in Pacific Far NE Russia during the Last Glacial Maximum
}

\author{
Iestyn D. Barr, \& Chris D. Clark
}

Department of Geography, University of Sheffield, Winter Street, Sheffield, S10 2TN, UK

This is an author produced version of a paper published in the Journal of Quaternary

Science

\section{Published paper}

Barr, ID., Clark, CD. (2011) Glaciers and climate in Pacific Far NE Russia during the Last Glacial Maximum. Journal of Quaternary Science, 26 (2), 227-237. doi: 10.1002/jqs.1450

http://onlinelibrary.wiley.com/doi/10.1002/jqs.1450/full 


\begin{abstract}
A combined geomorphological - physical model approach is used to generate threedimensional reconstructions of glaciers in Pacific Far NE Russia during the global Last glacial Maximum (gLGM). The horizontal dimensions of these ice masses are delineated by moraines, their surface elevations are estimated using an iterative flowline model, and temporal constraints upon their margins are derived from published age-estimates. The Equilibrium-line altitudes (ELAs) of these ice masses are estimated, and gLGM climate is reconstructed using a simple degree-day melt model.
\end{abstract}

The results indicate that, during the gLGM, ice masses occupying the Pekulney, Kankaren and Sredinny mountains of Pacific Far NE Russia were of valley-glacier and ice-field type. These glaciers were between 7 and $80 \mathrm{~km}$ in length, and were considerably less extensive than during pre-LGM phases of advance. gLGM ice masses in these regions had ELAs of between $575 \pm 22 \mathrm{~m}$ and $1035 \pm 41 \mathrm{~m}$ (a.s.1.) - corresponding to an ELA depression of 350$740 \mathrm{~m}$, relative to present. Data indicate that, in the Pekulney Mountains, this ELA depression occurred because of a $6.4^{\circ} \mathrm{C}$ reduction in mean July temperature, and $200 \mathrm{~mm} \mathrm{yr}^{-1}$ reduction in precipitation, relative to present.

Thus, reconstructions support a restricted view of gLGM glaciation in Pacific Far NE Russia, and indicate that the region's aridity precluded the development of large continental ice sheets. 


\section{Introduction}

Over recent decades, the glacial history of Far NE Russia has been a matter of considerable contention, with debate focussing upon the style and extent of ice masses during the global Last Glacial Maximum (gLGM; approximately $21 \mathrm{ka}$; referred to in Russian literature as the Sartan). During this period, some consider the region to have been occupied by a series of vast and coalescing ice sheets, forming the SE component of a larger pan-Arctic ice mass (Grosswald, 1988, 1998; Grosswald and Hughes, 1999, 2002, 2004), while others regard glaciers to have been of limited extent, and restricted to only the highest mountains (Velichko et al., 1984; Arkhipov et al., 1986; Glushkova, 1992, 2001; Laukhin, 1997, 2006; Gualtieri et al., 2000; Heiser and Roush, 2001; Velichko and Spasskaya, 2002; Brigham-Grette et al., 2003; Stauch et al, 2007; Stauch and Gualtieri, 2008; Barr and Clark, 2009). Part of the uncertainty regarding the dimensions of former ice masses in Far NE Russia results from the difficulties of conducting fieldwork in such an isolated region, and chronological control upon former phases of ice advance is therefore limited, as age-estimates have been derived from few glacial deposits (Gualtieri et al. 2000; Glushkova, 2001; Anderson and Lozhkin, 2002; Brigham-Grette et al., 2003; Laukhin et al., 2006; Stauch et al., 2007). Various authors have presented depictions of the region's ice masses during the gLGM (Velichko et al., 1984; Arkhipov et al., 1986; Grosswald, 1988; Grosswald and Hughes, 2002; Zamoruyev, 2004), but it is apparent that robust, chronologically-constrained reconstructions, underpinned by detailed geomorphological maps are all but absent. As a result, our understanding of the regions climate during the gLGM is limited: as factors such as atmospheric circulation are difficult to constrain without knowledge of ice-surface topography. Felzer (2001), for example, found that simulations of the region's climate during the gLGM differ considerably when models are run with and without an ice sheet in Far NE Russia. Thus, generating robust reconstructions of gLGM ice masses in Far NE Russia is important, first because they are of use to the climate modelling community, but also because they may be used as independent proxies for palaeoclimate, through calculation of their equilibrium-line altitudes (ELAs) where net annual accumulation and ablation are exactly equal (see Porter, 1975, 2001; Sissons, 1979; Benn and Ballantyne, 2005).

This paper presents three-dimensional (3-D) reconstructions of ice masses in the Pekulney, Kankaren and Sredinny mountains of Pacific Far NE Russia during the gLGM. These reconstructions are generated through a combined geomorphological - physical model 
approach, and restricted to areas where regional chronologies allow ice-mass margins to be constrained to the gLGM (see Stauch and Gualtieri, 2008). Palaeo-ELA estimates are derived from these reconstructions, and inferences made regarding climatic conditions during the gLGM. The paper is the first to present chronologically- and geomorphologically-constrained reconstructions of gLGM ice masses in Far NE Russia, and advances our understanding of the glacial- and climatic-history of this vast and little-investigated region.

\section{Regional Setting}

Far NE Russia extends east from the Lena River to the coast of the North Pacific, covers an area of almost 4 million $\mathrm{km}^{2}$ (Fig 1), and is dominated by a series of mountain chains, which rarely exceed $2500 \mathrm{~m}$ above sea level (a.s.l.). The region's climate is strongly continental, typically characterised by extreme aridity, cold winters and warm summers (Ivanov, 2002). During winter months the Siberian High pressure system develops over the continental interior, driving cold winds, and dry air-masses south and east towards the Aleutian Lowbranches of which occupy the Bering and Okhotsk Seas (Yanase and Abe-Ouchi, 2007). During summer months, a high pressure system develops over the North Pacific, driving moisture-bearing winds inland from the south and SE (Shahgedanova, 2002; Yanase and Abe-Ouchi, 2007). These conditions result in a severely cryo-arid interior, with amelioration towards the Pacific Coast. This paper focuses specifically upon the Pekulney, Kankaren and Sredinny Mountain Ranges (Fig 1), each of which lies within this Pacific sector, where conditions are often less extreme.

\subsection{The Pekulney Mountains}

The Pekulney Mountains (Fig 1) (centred upon $66.09^{\circ} \mathrm{N}, 175.05^{\circ} \mathrm{E}$ ) are located in the Chukchi region and extend, from north to south, for $130 \mathrm{~km}$, reaching altitudes of $1359 \mathrm{~m}$ (a.s.l.). Average winter temperatures range between -21 and $-29^{\circ} \mathrm{C}$, and average summer temperatures between +11 and $+14^{\circ} \mathrm{C}$ (Glushkova, 2001). The Pekulney Mountains are the first significant topographic barrier to the inland transport of moisture-laden air-masses from the Gulf of Anadyr, and precipitation, therefore, decreases from a maximum, of $475 \mathrm{~mm} \mathrm{yr}^{-1}$, on eastern slopes (Glushkova, 2001). At present, the mountains are occupied by very small cirque-type glaciers, but robust estimates of modern snowline altitudes are not recorded.

\subsection{The Kankaren Mountains}


The Kankaren Mountains (Fig 1) (centred upon $63.36^{\circ} \mathrm{N}, 177.04^{\circ} \mathrm{E}$ ) are situated at the NE fringe of the Koryak Highlands, $250 \mathrm{~km}$ SE of the Pekulney Mountains, and $60 \mathrm{~km}$ from the North Pacific coast. They extend from NW to SE for $60 \mathrm{~km}$ and are comparatively subdued, nowhere attaining altitudes in excess of $1000 \mathrm{~m}$ (a.s.l.). Direct estimates of modern climatic conditions within the mountains are lacking, as the closest World Meteorological Station is in Anadyr $\left(\sim 64.72^{\circ} \mathrm{N}, 177.49^{\circ} \mathrm{E}\right), 150 \mathrm{~km}$ to the north. As in the Pekulney Mountains, modern snowline altitudes are poorly-constrained.

\subsection{The Sredinny Mountains}

The Sredinny Mountains (Fig 1) (centred upon $56.55^{\circ} \mathrm{N}, 159.56^{\circ} \mathrm{E}$ ) form the central topographic divide of the Kamchatka Peninsula. They extend from north to south for $800 \mathrm{~km}$, and reach a maximum altitude of $3621 \mathrm{~m}$ (a.s.1.). Modern climatic conditions are difficult to classify, as the mountains encompass a range of topographic- and climatic-zones. Over the entire peninsula, mean temperatures range from +10 to $+15^{\circ} \mathrm{C}$ in July, and, in January, range from approximately $-8^{\circ} \mathrm{C}$ in SE regions to $-26^{\circ} \mathrm{C}$ in the NW (Ivanov, 2002). Mean annual precipitation also decreases from SE to NW, with values of $1500-2000 \mathrm{~mm}$ in the former, and 300-400 mm in the latter (Ivanov, 2002). Modern ELAs are highly variable, and Kamchatka currently constitutes the largest glacierised area in NE Asia, with 448 small, cirque-type, glaciers covering approximately $906 \mathrm{~km}^{2}$ (Solomina and Calkin, 2003, Ananicheva et al., 2008).

\section{Methods}

\subsection{Geomorphological mapping}

The glacial geomorphology of the whole of Far NE Russia, from the Lena River to the Pacific coast, including the Pekulney, Kankaren and Sredinny Mountains was mapped from satellite images and digital elevation model (DEM) data (for detailed maps and a description of the mapping procedure see Barr 2009; Barr and Clark, 2009). Many features indicative of former glaciation, including drumlins, trimlines and meltwater channels, were conspicuous by their scarcity, with only end moraines identifiable within many regions. In the present study, the morphology and orientation of these moraines was used in conjunction with land surface topography (particularly direction of slope), to infer palaeo ice-flow directions (as reported in Barr and Clark, 2009). Moraines were ascribed to the gLGM on the basis of 
published age estimates. In the Pekulney Mountains this was based upon a combined radiocarbon-cosmogenic chronology derived from a single moraine (Brigham-Grette et al., 2003). In the Kankaren Mountains, age-estimates were based on cosmogenic dating within the adjacent Koryak Mountains (see Gualtieri et al., 2000); whilst in the Sredinny Mountains, dating was based on a long-standing radiocarbon chronology (Olyunin, 1965; Braitseva et al., 1968; Vtyurin and Svitoch, 1978; Kraevaya et al., 1983; Melekestsev and Braitseva, 1984). In each mountain range, the spatial distribution of moraines was used to extrapolate ageestimates to a wide population, i.e. moraines were grouped according to their altitude and distance from regional mountain divides (considered to approximate palaeo-glacier length).

\subsection{Ice-mass reconstructions}

Ice masses were reconstructed in a GIS environment, with their horizontal dimensions defined by spatially-grouped moraines, and an iterative flowline model (Eq. 1) used to calculate their surface elevations along inferred ice-flowlines (see Schilling and Hollin, 1981).

$h_{i+1}=h_{i}+\frac{\tau_{a v}}{\rho g} \frac{\Delta x}{H}$

where $\mathrm{h}$ is ice surface height above the glacier terminus; $\mathrm{i}$ refers to the iteration number; $\tau_{\mathrm{av}}$ is average basal shear stress; $\rho$ is the density of ice; $g$ is gravitational acceleration; $\Delta x$ is step length (measured in metres); and $\mathrm{H}$ is ice thickness.

Ideally, the model is constrained by mapped indicators of ice-mass surface elevations (e.g. trimlines and/or lateral moraines), and basal shear stress is varied until the reconstructed ice surface matches these 'targets' (Murray and Locke, 1989). Where such indicators are lacking (as in the Pekulney, Kankaren and Sredinny Mountains) a constant basal shear stress may be applied to the entire profile, often based on estimates from modern glaciers (Nye, 1952; Kanasewitch, 1963; Schilling and Hollin, 1981; Locke, 1995; Rea and Evans, 2007). Here, however, as an alternative to arbitrarily selecting a basal shear stress, the elevations of reconstructed ice-mass surfaces were constrained through comparison with a dataset of modern ice-mass surface profiles (see Barr, 2009; Ng et al., 2010). Glacier surfaces were generated, using the iterative model, by extracting bed elevations at $1 \mathrm{~km}$ intervals along inferred flowlines, and defining the maximum elevation at the upper-end of each profile by 
equation (2), which corresponds to a 'typical' modern ice-mass surface (see Barr, 2009; Ng et al., 2010) (Fig 2).

$h=29.098 L^{0.343}$

where $\mathrm{L}$ is flowline length

This resulted in a series of point elevations, from which 3-D surfaces were generated in ArcGIS (Kriging interpolation with a fixed search radius of $10 \mathrm{~km}$ ). Raster subtraction of land-surface topography allowed ice thickness and ice-mass margins to be determined, and surfaces were then smoothed (maximum offset of $100 \mathrm{~m}$ ) and contoured using an automated GIS-process.

\subsection{Equilibrium-line altitude estimates}

A number of methods have been developed for estimating the palaeo-ELAs of reconstructed ice masses, and these vary in terms of their accuracy and simplicity of application (see Osmaston, 1975, 2005; Porter, 1977, 2001; Meierding, 1982; Kaser and Osmaston, 2002; Benn et al., 2005). Two of the most robust, and widely implemented, are the accumulation area ratio (AAR) (Porter, 1977; Kuhn, 1989; Benn and Lehmkuhl, 2000; Nesje and Dahl, 2000) and balance ratio (BR) methods (Furbish and Andrews, 1984; Benn and Gemmell, 1997; Benn and Lehmkuhl, 2000; Osmaston, 2005; Rea, 2009). The AAR method assumes that the ratio of the accumulation area of a glacier to its total area is roughly fixed between 0.5 and 0.8 (Meier and Post, 1962; Grosswald and Kotlyakov, 1969). In utilising the AAR method within the present study, values of 0.5 and 0.6 were used, as these are considered representative of mid- to high-latitude ice-masses (Grosswald and Kotlyakov, 1969; Sutherland, 1984), and the region of interest, in Pacific NE Russia, extends from 53 to $67^{\circ} \mathrm{N}$. The AAR method has been shown to produce consistent results (Porter, 2001), but its major weakness is that it fails to take account of glacier hypsometry (i.e. the altitudinal distribution of glacier surface-area), which can vary significantly from glacier-to-glacier and have a considerable impact upon ELA (Mercer, 1961; Furbish and Andrews, 1984; Nesje and Dahl, 2000). The BR method, by contrast, takes explicit account of both glacier hypsometry and altitudinal variation in mass-balance (Furbish and Andrews, 1984), and is, therefore, in principle, a better means of estimating ELA (Rea, 2009), and is widely becoming the 'method of choice' (e.g. Benn and Lehmkuhl, 2000; Kaser and Osmaston, 2002; Benn and Ballantyne, 
2005; Kovanen and Slaymaker, 2005; Rea and Evans, 2007; Vieira, 2008; Cowton et al., 2009). The key variable in applying this method defines the ratio of the mass-balance gradient in the ablation zone of a glacier to the mass-balance gradient in the accumulation zone, and is termed the balance ratio (BR). BRs of modern glaciers are typically found to range from 1.67 to 2.2 (though values can lie well outside this range) (Furbish and Andrews, 1984; Rea, 2009), with low-latitude, dynamic glaciers exhibiting values towards the higher end of this range, as the vertical change in mass-balance within the ablation zones of such glaciers is significantly greater than within their accumulation zones. A BR of around 2.0 is considered characteristic of maritime, mid-latitude glaciers, and values below this are considered representative of high-latitude glaciers (Furbish and Andrews, 1984; Rea, 2009). The BR method was used within the present study, using the spreadsheet provided by Benn and Gemmell (1997), with BRs of 1.67, 1.8 and 2.0 selected in order to encompass Arctic high-latitude to maritime mid-latitude glaciers. This study focuses upon these estimates derived using the BR method, as these are considered most robust, with AAR-ELA estimates simply shown for comparison.

Palaeo-ELA estimates were calculated for individual glaciers and ice-catchments, allowing both regional and inter-regional trends to be evaluated. Where appropriate, and in order to illustrate the climatically-driven component of ELA-variability, third-order polynomial trend surfaces were also generated from these estimates (see Balascio et al., 2005).

\subsection{Palaeo-climatic inferences}

Based upon palaeo-ELA estimates, a degree-day model was used to yield climatic information from the reconstructed ice mass in the Pekulney Mountains (see Braithwaite et al. 2006; Brugger, 2006; Hughes and Braithwaite, 2008; Hughes, 2009). Simpler, empirical methods (e.g. Ohmura, 1992) of deriving climatic information from glacier ELAs have been used elsewhere (e.g. Benn and Ballantyne, 2005; Ballantyne 2007a,b; Golledge, 2007; Rea and Evans, 2007; Smith et al., 2009), but are found to overestimate palaeo-precipitation under strongly continental conditions, where the annual range in temperatures is large (see Hughes and Braithwaite, 2008; Hughes, 2009), as in Far NE Russia.The degree-day model was used to calculate the annual accumulation necessary to balance annual ablation (melt less any superimposed ice) at the palaeo-ELA of the reconstructed ice mass (Braithwaite et al., 2006). Daily melt was calculated for each day of the year as a function of daily mean 
temperature $\left(\mathrm{T}_{\mathrm{d}}\right.$ ), using a degree-day factor of $4 \mathrm{~mm}$ day ${ }^{-1}{ }^{\circ} \mathrm{C}^{-1}$ (Braithwaite et al. 2006; Brugger, 2006; Hughes, 2009), and annual accumulation was assumed to equal the annual sum of these daily melt values (See Brugger, 2006; Hughes and Braithwaite, 2008; Hughes, 2009). Daily mean temperatures during the gLGM were calculated from estimates of mean annual temperature during this period using equation (3) (from Brugger 2006), by assuming that a sine curve, defined by annual temperature range, approximates the annual distribution of temperatures (see Hughes and Braithwaite, 2008; Hughes, 2009).

$$
T_{d}=A_{y} \sin \left(\frac{2 \pi d}{\lambda}-\Phi\right)+T_{a}
$$

where $A_{y}$ is the amplitude of annual temperature variations ( $1 / 2$ the annual temperature range), $\mathrm{d}$ is the ordinal day, $\lambda$ is the period (365 days), $\Phi$ is the phase angle of the sine curve (taken as 1.93 radians to reflect the fact that January is the coolest month, and July the warmest), and $\mathrm{T}_{\mathrm{a}}$ is the is the mean annual air temperature.

Thus, the inputs required to estimate mean annual accumulation at the palaeo-ELA of the reconstructed ice mass were annual temperature range and mean annual temperature during the gLGM. The former was estimated from modern climate data which indicates that, at present, the annual range in air temperatures in the Pekulney Mountains is between 32 and $43^{\circ} \mathrm{C}$ (Glushkova, 2001). The higher of these values was considered an estimate for gLGM conditions, in recognition that sea level reduction and extensive sea ice, amongst other factors, are likely to have increased the region's continentality (and, therefore, annual temperature range) during this period. Mean annual temperature during the gLGM was calculated from published estimates of mean July temperature during this period, obtained, through pollen analysis, from El'gygytgyn Lake $\left(\sim 67^{\circ} \mathrm{N}, 172^{\circ} \mathrm{E} ; 495 \mathrm{~m}\right.$ a.s.l.) (Lozhkin et al., 2007) - $150 \mathrm{~km} \mathrm{NW}$ of the Pekulney Mountains. These data indicate that, at the El'gygytgyn site, mean July air temperatures during the gLGM were $2-3^{\circ} \mathrm{C}$. However, modern data indicate that summer temperatures at El'gygytgyn Lake are typically below those at a corresponding altitude in the Pekulney Mountains (World Meteorological Organisation, 1998), and estimates at the higher end of the $2-3^{\circ} \mathrm{C}$ range might, therefore, better reflect mean July air temperatures in the Pekulney Mountains during the gLGM. Given a value of $3^{\circ} \mathrm{C}$ (the maximum at El'gygytgyn), and assuming an environmental lapse rate of $0.63^{\circ} \mathrm{C} 100 \mathrm{~m}^{-1}$ 
(Osipov, 2004), yields a gLGM July temperature at present sea level of $6.1^{\circ} \mathrm{C}$. This value was distributed over an annual temperature range of $43^{\circ} \mathrm{C}$ (with the annual distribution of mean monthly temperatures assumed to approximate a sine curve), in order to obtain an estimate of mean annual temperature. Using the lapse rate of $0.63^{\circ} \mathrm{C} 100 \mathrm{~m}^{-1}$, this estimate was then extrapolated to the palaeo-ELAs of the reconstructed ice mass in the Pekulney Mountains, and the degree-day model (Eq. 3) was then used to estimate mean annual ablation, and therefore, mean annual accumulation, at these altitudes. The use of the above model in reconstructing gLGM accumulation was restricted to the Pekulney Mountains, as (to the authors' knowledge) no independent estimates of gLGM air temperatures have been obtained in the vicinity of the Kankaren or Sredinny Mountains, and such estimates are vital to the model's implementation.

\section{Results}

\subsection{The Pekulney Mountains}

The Pekulney Mountains are currently occupied by a small number of cirque-type glaciers, and numerous glacial valleys, cirques and end moraines are testament to the former presence of extensive valley glaciers (see Baranova, 1960; Kartashov, 1962; Gasanov, 1969; Glushkova and Sedov, 1984; Glushkova, 1992, 1996, 2001; Brigham-Grette et al., 2003; Barr and Clark, 2009). These end moraines appear, on the basis of their spatial distribution, to fall into two distinct populations. The outer population (Fig 3) is deemed to reflect ice extent during some, unspecified, pre-gLGM phase of advance, while the inner population is constrained to the gLGM by a combined radiocarbon-cosmogenic chronology (BrighamGrette et al., 2003) from moraines and river-terraces within the Kuveveem valley (Fig 3). Generating an ice-mass reconstruction from this inner population indicates that, during the gLGM, the Pekulney Mountains were occupied by a mountain-centred ice field, with outlet glaciers extending up to $21 \mathrm{~km}$ within surrounding valleys (Fig 3). This 'Pekulney Ice Field' reached an altitude of $1211 \mathrm{~m}$ (a.s.l.) and occupied $970 \mathrm{~km}^{2}$. The total ice volume was 241 $\mathrm{km}^{3}$, with a maximum thickness of $806 \mathrm{~m}$, and an average flowline basal shear stress of 117 $\mathrm{kPa}$. The ice field yields a mean palaeo-ELA of $743 \pm 27 \mathrm{~m}$ (a.s.l.) (Table 1), given a 95\% confidence interval and a BR range of 1.67-2.0, while values for individual catchments (outlets) (Fig 4) show a clear gradient, from a mean of $652 \pm 27 \mathrm{~m}$ (a.s.l.) to the east of the 
range, to $842 \pm 25 \mathrm{~m}$ (a.s.l.) to the west (Fig 3). These values compare to gLGM ELA estimates of 600-830 m (a.s.1.) as derived by Glushkova (1992), based on cirque floor altitudes and the arithmetic mean between the elevation of the lowest point of a glacier and the mean elevation of mountain summits surrounding its accumulation zone-two comparatively crude (but useful) estimators of palaeo-ELA. This latter approach is known in Russian literature as Gefer's method (see Osipov, 2004), and was originally developed by Höfer (1879).

The palaeo-temperature estimate derived from the El'gygytgyn Lake pollen data (Lozhkin et al., 2007) indicate that, during the gLGM, at the palaeo-ELA of the western and eastern sectors of the Pekulney Ice Field, mean July temperatures were $0.8 \pm 0.2^{\circ} \mathrm{C}$ and $2.0 \pm 0.2^{\circ} \mathrm{C}$, respectively. Using these values as inputs to the degree-day model yields mean annual accumulation estimates of $69 \pm 19 \mathrm{~mm}$ (w.e.) at the ELA of the western sector, and $269 \pm 33$ $\mathrm{mm}$ (w.e.) at the ELA of the eastern.

\subsection{The Kankaren Mountains}

The Kankaren Mountains are currently devoid large of glaciers, but are dissected by large north-south trending valleys, which, in conjunction with numerous end moraines and drift sheets, indicate the former presence of extensive ice masses (Gualtieri et al., 2000; Barr, 2009; Barr and Clark, 2009). A total of 28 end moraines are identifiable within close proximity to the mountains (within $10 \mathrm{~km}$ ), and these appear to represent a single, synchronously-deposited, population. Upon the basis of a regional cosmogenic chronology (Gualtieri et al., 2000), these moraines are deemed to reflect ice extent during the gLGM, with evidence upon the Lower Anadyr Depression of earlier, more extensive, phases of iceadvance (Gualtieri et al., 2000; Barr and Clark, 2009). A reconstruction (Fig 5) was generated on the basis of the inner population, and suggests that, during the gLGM, the western sector of the Kankaren Mountains was occupied by a single mountain-centred ice field, while the eastern sector was occupied by a group of five, partially-coalesced, valley glaciers. These icemasses extended up to $7 \mathrm{~km}$ in length, occupied a total area of $215 \mathrm{~km}^{2}$, and constituted an ice volume of $31 \mathrm{~km}^{3}$. The maximum ice surface altitude (attained by the ice field sector) was $937 \mathrm{~m}$ (a.s.l.) (the mountains reach a maximum altitude of roughly $1180 \mathrm{~m}$ a.s.l.), the maximum ice thickness was $452 \mathrm{~m}$, and average flowline basal shear stress was $119 \mathrm{kPa}$. These ice masses yield a mean palaeo-ELA of $575 \pm 22 \mathrm{~m}$ (a.s.1.) (Table 1), given a 95\% 
confidence interval and a BR range of 1.67-2.0, while estimates for individual glaciers and catchments vary considerably (from 441 to $726 \mathrm{~m}$ a.s.l.)(Fig 4). These values compare to gLGM ELA estimates of 400-550 m (a.s.1.), as derived by Glushkova (1992), based on cirque floor altitudes and using Gefer's method (see section 4.1). There appear not to be any clear ELA gradients within this region, but there is a strong contrast between glaciers to the north of the range, which extend below $200 \mathrm{~m}$ (a.s.1.), and those to the south, which rarely extend below $400 \mathrm{~m}$ (a.s.1.) - a contrast which, along with the absence of south-facing glaciers in the eastern massif, would appear to suggest a variation in palaeo-ELA between north- and south-facing slopes. Though the reconstruction in fig 5 focuses upon gLGM ice extent in the Kankaren Mountains specifically, the Mejngypilgynskij Mountains, approximately $50 \mathrm{~km}$ to the south, are also believed to have been occupied by extensive valley glaciers which extended to the southern foothills of the Kankaren Range during this period (see Gualtieri et al., 2000).

\subsection{The Sredinny Mountains}

At present, glaciers occupy only the highest peaks of the Sredinny Mountains, and are mainly of small cirque-type. However, various lines of evidence, including end moraines and glacially eroded valleys, testify to the former presence of extensive ice masses (Lapshin, 1963; Vlasov, 1964; Olyunin, 1965, 1966; Braitseva et al., 1968; Kuprina, 1970; Vtyurin and Svitoch, 1978; Kraevaya et al., 1983; Zech et al., 1997; Savoskul and Zech, 1997; Zamoruyev, 2004; Bäumler and Zech, 2000; Leonov and Kobrenkov, 2003; Solomina and Calkin, 2003; Bigg et al., 2008; Barr and Clark, 2009). A total of 204 end moraines have been identified and mapped in, and around, the Sredinny Mountains (Fig 6) (78 of which were mapped by Bigg et al., 2008, and the remainder by Barr and Clark, 2009), and there appear to be at least two distinct groups: one immediately adjacent to the mountains, and another closer to the coast. Radiocarbon dating indicates that the inner population was deposited during the gLGM (Olyunin, 1965; Braitseva et al., 1968; Vtyurin and Svitoch, 1978; Kraevaya et al., 1983; Melekestsev and Braitseva, 1984; Zech et al., 1997; Savoskul and Zech, 1997; Bäumler and Zech, 2000; Solomina and Calkin, 2003), whilst comparison with marine records indicates that the outer population was deposited sometime prior to $40 \mathrm{ka}$ (Bigg et al., 2008). An ice-mass reconstruction is here generated from the inner population, and appears to indicate that, during the gLGM, the Sredinny Mountains were occupied by a single mountain-centred ice field with outlet glaciers extending up to $80 \mathrm{~km}$ into surrounding 
valleys (Fig 6). This 'Sredinny Ice Field' occupied an area of 57,363 km², and comprised an ice volume of 22,147 $\mathrm{km}^{3}$. Ice extended from $65 \mathrm{~m}$ below modern sea level (approximately $60 \mathrm{~m}$ above the inferred gLGM sea level; see Yokoyama et al., 2001), to a maximum of 1731 $\mathrm{m}$ (a.s.1.). Ice thickness peaked at $1114 \mathrm{~m}$, and the average flowline basal shear stress was 76 $\mathrm{kPa}$. The ice field yields a mean palaeo-ELA of $897 \pm 21 \mathrm{~m}$ (a.s.1.) (Table 1), given a 95\% confidence interval and a BR range of 1.67-2.0, yet values for the 112 separate catchments vary considerably, from 470 to $1238 \mathrm{~m}$ (a.s.l.) (Fig 4). There is no clear west-east gradient, but values increase from a mean of $808 \pm 34 \mathrm{~m}$ (a.s.1.) in the northern sector $\left(>58^{\circ} \mathrm{N}\right)$, through $876 \pm 31 \mathrm{~m}$ (a.s.1.) in the north-central sector $\left(56-58^{\circ} \mathrm{N}\right)$, to $1035 \pm 41 \mathrm{~m}$ (a.s.1.) in the southern-central sector $\left(54-56^{\circ} \mathrm{N}\right)$, before descending again to $860 \pm 38 \mathrm{~m}$ (a.s.1.) in the southern sector $\left(<54^{\circ} \mathrm{N}\right)$ (Fig 6). These values may be compared to gLGM ELA estimates of 550 - 600 m (a.s.1.) (based on AARs of 0.58 and 0.55) derived by Savoskul and Zech (1997) from the Topolovaya Valley $\left(\sim 53.18^{\circ} \mathrm{N}, 158.03^{\circ} \mathrm{E}\right)$, some $40 \mathrm{~km}$ east of the southernmost ice in the Sredinny Range.

In discussing former glaciation and palaeo-ELA within the Sredinny Mountains, it is necessary to consider the influence of postglacial tectonic processes, as the Kamchatka Peninsula lies close to the subducting Pacific Plate, and is occupied by numerous active and extinct volcanoes (Ivanov, 2002). During the Late Quaternary, volcanoes within the Sredinny Mountains were active, but the structural elements of these volcanoes were in place prior to this (Braitseva et al., 1995; Koronovsky, 2002). Robust estimates of postglacial uplift or subsidence within the Sredinny Mountains are lacking, but in general, much of the Kamchatka Peninsula has undergone uplift since the gLGM (Pinegina and Bourgeois, 2001). However, this uplift is not ubiquitous, and varies depending on location-with subsidence dominating in some parts (Fedotov et al., 1988). On the Kamchatskiy Peninsula (centred upon $56.42^{\circ} \mathrm{N}, 163.20^{\circ} \mathrm{E}$ ), roughly $180 \mathrm{~km}$ east of the central Sredinny Mountains, the mapping of marine terraces reveals that average Late Quaternary uplift rates range from 0.1 to $1.0 \mathrm{~mm} \mathrm{yr}^{-1}$ (Pedoja et al., 2004). However, on the NE part of the Ozernoi Peninsula (centred upon $57.68^{\circ} \mathrm{N}, 162.91^{\circ} \mathrm{E}$ ), roughly $140 \mathrm{~km}$ east of the north-central Sredinny Mountains, terraces indicate Late Quaternary uplift rates of 0.1 to $0.3 \mathrm{~mm} \mathrm{yr}^{-1}$ (Pedoja et al., 2006). As a result of the proximity of these regions to the continental margin, these estimates are comparable to rates in tectonically active regions (Pedoja et al., 2006), and postglacial uplift here is likely to have been more intense than, inland, within the Sredinny Mountains. If, as an example, a maximum rate of $1.0 \mathrm{~mm} \mathrm{yr}^{-1}$ is considered representative of the Sredinny 
Mountains, then a net post-gLGM uplift of roughly $20 \mathrm{~m}$ might be inferred. As this is considered a maximum estimate, and remains a comparatively small value, postglacial tectonic activity within the Sredinny Mountains is not regarded to have had a significant impact upon palaeo-ELA estimates derived within this study, and no correction for tectonic processes is made here.

\section{Discussion}

\subsection{Ice extent}

The methodology adopted within this study has allowed the first geomorphologically- and chronologically-constrained 3-D palaeo ice-mass reconstructions to be generated for Pacific Far NE Russia. These reconstructions are of gLGM ice-masses within the Pekulney, Kankaren and Sredinny Mountains, and, given the prevalence of end moraines elsewhere (see Barr and Clark, 2009), it might be inferred that, during this period, many adjacent mountain ranges, particularly in the Koryak sector, were also occupied by extensive ice masses, some of which may have extended to the gLGM coastline (conservatively, we have restricted our analysis to only those regions with dating control). The reconstructions indicate that, during the gLGM, ice masses in the Pekulney, Kankaren and Sredinny Mountains were of ice-field and valley-glacier type, mountain-centred, and extended between 7 and $80 \mathrm{~km}$ into surrounding valleys. Numerous moraines are identifiable beyond these margins, indicating that ice masses were considerably more extensive during some pre-gLGM phase(s) of advance, perhaps during the Zyryan ( 110-50 ka), and/or some, unspecified, pre-Zyryan phase (Gualtieri et al., 2000; Brigham-Grette et al., 2003; Laukhin et al., 2006; Bigg et al., 2008). During the most extensive of these advances, some of the largest ice cap systems may have extended up to $200 \mathrm{~km}$ beyond regional mountain centres (Barr and Clark,2009) but our investigation and mapping revealed no evidence to suggest the former presence of extensive ice sheets within the region (cf. Grosswald, 1988, 1998; Grosswald and Hughes, 1999, 2002, 2004).

\subsection{Glacier-climate reconstructions}

The palaeo-ELA estimates derived in this study inform us about climate during the gLGM. They take both glacier hypsometry and assumed mass-balance gradients into consideration, and are, therefore, considered the most robust yet obtained for Pacific Far NE Russia (cf. 
Glushkova, 1992; Savoskul and Zech, 1997). Some of the spatial variability in these estimates is likely due to local (non-climatic) controls, but may also result from errors intrinsic to the reconstruction methodology (i.e. the lack of absolute dating in most areas, requiring the synchronicity of ice-margins to be assumed). However, in regions where we find discernable trends in palaeo-ELA estimates, broad-scale variations likely reflect true palaeo-climatic gradients.

Outlets of the Pekulney Ice Field show a clear trend of increasing palaeo-ELAs from a mean of $652 \pm 27 \mathrm{~m}$ (a.s.1.) to the east of the range, to a mean of $842 \pm 25 \mathrm{~m}$ (a.s.1.) to the west (Fig 3). This is consistent with an inland precipitation gradient, with moisture-baring winds from the North Pacific providing precipitation to eastern slopes, depressing palaeo-ELA; and a precipitation-shadow to the west forcing higher values. Outlets of the Sredinny Ice Field also exhibit distinct palaeo-ELA gradients, with values descending below $700 \mathrm{~m}$ (a.s.1.) to the north, and below $800 \mathrm{~m}$ (a.s.l.) to the south, from a maximum of over $1100 \mathrm{~m}$ (a.s.l.) at roughly $55^{\circ} \mathrm{N}$ (Fig 6). The considerable altitude of the equilibrium-line in the south-central sector coincides with less-extensive glacier outlets, and likely reflects a regional rain-shadow, as the Vostočny Mountains (see Fig 6) — considered to have formed roughly 80-40,000 years ago (Braitseva and Melekestsev, 1966; Erlich et al., 1972) — created an orographic barrier to moisture-bearing, easterly, winds from the North Pacific. The lowering of palaeo-ELA towards the SW and, particularly, NE of the mountains, also appears to reflect a precipitation gradient, as these regions are in proximity to the Okhotsk and Bering Seas, respectively, where moisture availability, during the gLGM, is likely to have been maximised. Regional palaeo-ELA trends are not discernable within the Kankaren Mountains, though it is here that mean values are lowest at $575 \pm 22 \mathrm{~m}$ (a.s.1.), potentially reflecting the region's comparative proximity to the gLGM coastline (i.e. within $100 \mathrm{~km}$ )(see Fig 1).

In the Pekulney and Kankaren Mountains, ELA depression during the gLGM ( $\triangle \mathrm{ELA}$ gLGM), relative to present, is difficult to quantify, as modern ELAs are poorly constrained. Shahgedanova et al. (2002), for example, depict the modern ELA as lying at roughly $900 \mathrm{~m}$ (a.s.1.) to the west of the Pekulney Mountains and $600 \mathrm{~m}$ (a.s.1.) to the east. These estimates appear very low, and bear little relation to the current distribution of glaciers within the mountains. Published estimates of modern ELA within the Kankaren Mountains are not 
available, but in the Mejngypilgynskij Mountain Range, approximately $50 \mathrm{~km}$ to the south, modern ELA estimates range from 450 to $700 \mathrm{~m}$ (a.s.1.) (Gualtieri et al., 2000). Though these values are potentially representative of the Kankaren Mountains, this assumption is difficult to fully justify as modern snowline elevations (a surrogate for ELAs) across the Koryak region, in general, are highly variable: ranging from $280 \mathrm{~m}$ (a.s.1.) in coastal regions to 2080 m (a.s.1.) in-land (NSIDC, 2009). In the Sredinny Mountains of Kamchatka modern snowline altitudes are also known (NSIDC, 2009), and illustrate that ELA depression during the gLGM ( $\triangle$ ELA gLGM), relative to present, varied from $\sim 358 \mathrm{~m}$ in the northern sector, to $\sim 739 \mathrm{~m}$ in more central regions (Fig 6). These values compare to $\triangle$ ELA (gLGM) estimates of 1105-1250 in the Hidaka Range, Japan (Ono et al., 2005), and 200-700 $\mathrm{m}$ in the Brooks Range, Alaska (Balascio et al., 2005), respectively $1600 \mathrm{~km}$ and $2400 \mathrm{~km}, \mathrm{SW}$ and NE of the Sredinny Range.

As ELA is largely governed by summer temperature and winter precipitation, a depression relative to present might be inferred as reflecting a decrease in the former and/or increase in the latter. At the palaeo-ELA of the western and eastern sectors of the Pekulney Ice Field, average mean July temperatures over the period 1961-1990 (World Meteorological Organisation, 1998) were 7.2 and $8.4^{\circ} \mathrm{C}$, respectively (based on values from Markovo and Anadyr weather stations, corrected to altitudes of 842 and $652 \mathrm{~m}$ a.s.l., respectively). The independent palaeo-temperature estimate from El'gygytgyn Lake indicates that during the gLGM mean July temperatures at these altitudes were $0.8 \pm 0.2^{\circ} \mathrm{C}$ and $2.0 \pm 0.2^{\circ} \mathrm{C}$ Thus, the data indicate a reduction in mean July temperature of $6.4^{\circ} \mathrm{C}$, relative to present. Mean annual precipitation to the east of the range is currently $475 \mathrm{~mm}$ (Glushkova, 2001), and the degreeday model predicts gLGM accumulation of between $69 \pm 19$ and $269 \pm 33 \mathrm{~mm}$ w.e. $\mathrm{yr}^{-1}$, to the west and east of the range, respectively. These modern precipitation and palaeo accumulation estimates cannot be compared directly, as they measure different things, with mean annual accumulation excluding precipitation during the ablation season, and including indirect sources of accumulation, such as windblown snow. However, as the Pekulney Ice Field occupies much of the land surface of the Pekulney Mountains, and is an independent (i.e. non-coalesced) ice mass, windblown snow is unlikely to have been a significant contributor to accumulation. Also, the degree-day model calculates that, during the gLGM, the ablation season lasted only 29-35 days (number of positive degree days) at the ELA of the western sector of the Pekulney Ice Field, and 48-53 days at the ELA of the eastern sector. 
Thus annual accumulation in the Pekulney Mountains during the gLGM might be considered a rough approximation of annual precipitation, and the data, therefore, indicate a reduction of roughly $200 \mathrm{~mm} \mathrm{yr}^{-1}(42 \%)$, relative to present.

Such a decrease in precipitation is consistent with the generalised view of conditions in Pacific Far NE Russia during the gLGM, as (i) a lowering of global sea levels resulted in the exposure of vast areas of continental shelf, particularly along the Arctic and Bering Sea coasts, and restricted the transport of warm waters from the north-central Pacific (Laukhin et al., 2006; Yanase and Abe-Ouchi, 2007); (ii) the extent of sea ice was increased (see Caissie et al., 2010); (iii) the development of vast ice sheets in North America and Europe altered atmospheric circulatory patterns (Stauch and Gualtieri, 2008); and (iv) much of the region's available moisture was trapped in glacier and ground ice (Sergin and Scheglova, 1976). Climate model simulations appear to support the view that annual precipitation was reduced, but indicate that this reduction was most extreme during summer months with the volume of winter precipitation potentially differing little from present (see Yanase and Abe-Ouchi, 2007). It is, therefore, possible to envisage glacial advance during this period despite a reduction in mean annual precipitation, as a decrease in summer temperatures resulted in a shortened ablation season, a lengthened accumulation season, and an increase in the volume of 'solid' precipitation. However, the estimates obtained from the Pekulney Ice field indicate that, during the gLGM, mean annual accumulation remained very low, i.e. between $69 \pm 19$ and $269 \pm 33 \mathrm{~mm}$ w.e. These values may be put into context by considering mass balance records from modern glaciers. Of the 63 modern ice masses for which the WGMS (2008) provide data, only 6 experience mean winter mass-balance values below $269 \pm 33 \mathrm{~mm}$ w.e, and only two have values at, or below, $69 \pm 18 \mathrm{~mm}$ w.e. The estimates derived here, therefore, suggest that, during the gLGM, annual accumulation and ablation in the Pekulney Mountains were low, and the region was occupied by a comparatively inactive and, therefore minimally-erosive, ice field-similar in character to modern Arctic-type glaciers such as those on Axel Heiberg Island, where the melt season at the ELA is as short as 27 days (Braithwaite and Raper, 2007).

Some (e.g. Alfimov and Berman, 2001) have suggested that mean July temperatures in Pacific Far NE Russia during the gLGM were, in fact, considerably higher than indicated by the El'gygytgyn data, and such estimates would have implications for the palaeo-precipitation 
estimates derived here. For example, if gLGM mean July temperatures are assumed to have been $9-10^{\circ} \mathrm{C}\left(3.1-4.1^{\circ} \mathrm{C}\right.$ blow present) at Markovo (as proposed by Alfimov and Berman, 2001), maintaining equilibrium conditions for the Pekulney Ice Field (250 km NE) would require mean annual accumulation (as calculated using the degree-day model) of at least 719 $\pm 44 \mathrm{~mm}$ (w.e.) to the west of the range, and $1081 \pm 46 \mathrm{~mm}$ (w.e.) to the east: an increase in precipitation of at least $606 \mathrm{~mm} \mathrm{yr}^{-1}(126 \%)$, relative to present. Though these conditions would result in dynamic and potentially erosive glaciers, there is very little published evidence in support of such an increase in precipitation, and it appears counter to our understanding of environmental conditions in the region during this period. It is, therefore, difficult to envisage gLGM July temperatures as high as those proposed by Alfimov and Berman (2001), and a decrease in mean July temperature of roughly $6.4^{\circ} \mathrm{C}$, relative to present, is supported here. This disparity between the data derived from El'gygytgyn Lake and that from Markovo highlights the need for additional independent estimates of air temperature in Pacific Far NE Russia during the gLGM.

\section{Conclusions}

A combined geomorphological - physical model approach to the reconstruction of former ice-masses in Pacific Far NE Russia indicates that, during the gLGM, the Pekulney, Kankaren and Sredinny Mountains were occupied by ice fields and valley glaciers, extending no more than $80 \mathrm{~km}$ beyond mountain-centres. These reconstructions support a minimalist view of glaciation, and are inconsistent with the belief that extensive ice sheets occupied the region during this period. Palaeo-ELA estimates derived from these reconstructions yield mean values of $652 \pm 27 \mathrm{~m}$ (a.s.l.) to the east of the Pekulney Mountains, $842 \pm 25 \mathrm{~m}$ (a.s.l.) to the west; $575 \pm 22 \mathrm{~m}$ (a.s.l.) in the Kankaren Mountains; and, upon the Kamchatka Peninsula, $808 \pm 34,876 \pm 31,1035 \pm 41$, and $860 \pm 38 \mathrm{~m}$ (a.s.1.), in the north, north-central, south-central, and southern sectors of the Sredinny Range-indicating an ELA depression of $\sim 350-740 \mathrm{~m}$, relative to present (though modern values are poorly constrained). Regional variations in palaeo-ELA appear to correspond to moisture availability and palaeoprecipitation gradients. Pollen data from El'gygytgyn Lake (Lozhkin et al., 2007) indicate that, during the gLGM, mean July temperatures at the palaeo-ELA of the Pekulney Ice Field were between $8 \pm 0.2^{\circ} \mathrm{C}$ and $2.0 \pm 0.2^{\circ} \mathrm{C} \quad\left(6.4^{\circ} \mathrm{C}\right.$ below modern values). Utilising these estimates as inputs to a degree-day model (e.g. Brugger, 2006), and assuming an annual 
temperature range of $43^{\circ} \mathrm{C}$, indicates mean annual accumulation of between $69 \pm 19$ and 269 $\pm 33 \mathrm{~mm}$ (w.e.) - suggesting that mean precipitation during the gLGM was, perhaps, $200 \mathrm{~mm}$ $\mathrm{yr}^{-1}$ below modern values. Based upon these data it is envisaged that, during the gLGM, the development of large ice sheets in Pacific Far NE Russia was precluded by the region's aridity, and that glaciers were only more extensive than present because of a reduction in summer air temperatures, and a resulting decrease in ablation. 


\section{References}

Alfimov AV, Berman DI. 2001. Beringian climate during the Late Pleistocene and Holocene. Quaternary Science Reviews 20: 127-134. DOI: 10.1016/S0277-3791(00)00128-1

Ananicheva MD, Krenke AN, Hanna E. 2008. Mountain glaciers of NE Asia in the near future: a projection based on climate-glacier systems interaction. The Cryosphere Discussions 2: 1-21. DOI: $\underline{10.5194 / \mathrm{tcd}-2-1-2008}$

Anderson PM, Lozhkin AV (Eds.). 2002. Late Quaternary Vegetation and Climate of Siberia and the Russian Far East: A Palynological and Radiocarbon Database. NOAA Paleoclimatology and North East Science Center: Magadan.

Arkhipov SA, Isaeva LL, Bespaly VG, Glushkova O. 1986. Glaciation of Siberia and Northeast USSR. Quaternary Science Reviews 5: 463-474.

Balascio NL, Kaufman DS, Manley WF. 2005. Equilibrium-line altitudes during the Last Glacial Maximum across the Brooks Range, Alaska. Journal of Quaternary Science 20: 821838. DOI: $\underline{10.1002 / \text { jqs. } 980}$

Ballantyne CK. 2007a. Loch Lomond Stadial glaciers in North Harris, Outer Hebrides, North-West Scotland: glacier reconstruction and palaeoclimatic implications. Quaternary Science Reviews 26: 3134-3149. DOI: 10.1016/j.quascirev.2007.09.001

Ballantyne CK. 2007b. The Loch Lomond Readvance on north Arran, Scotland: glacier reconstruction and palaeoclimatic implications. Journal of Quaternary Science 22: 343-359. DOI: $\underline{10.1002 / j q s .1059}$

Baranova Y. 1960. To the history of relief development of the Lower-Anadyr lowland and surrounding mountains in Quaternary period. Geology and Geophysics 12: 72-85. (In Russian). 
Barr ID. 2009. Constraining the extent, style and phases of glaciation to derive Late Quaternary equilibrium-line altitude estimates in Far NE Russia. Ph.D. Thesis, University of Sheffield, UK.

Barr ID, Clark CD. 2009. Distribution and pattern of moraines in Far NE Russia reveal former glacial extent. Journal of Maps 2009: 186-193. DOI: 10.4113/jom.2009.1108

Bäumler R, Zech W. 2000. Quaternary paleosols, tephra deposits and landscape history in South Kamchatka, Russia. Catena 41: 199-215. DOI: 10.1016/S0341-8162(00)00100-4

Benn DI, Ballantyne CK. 2005. Palaeoclimatic reconstructions from Loch Lomond Readvance glaciers in the West Drumochter Hills, Scotland. Journal of Quaternary Science 20: 577-592. DOI: $\underline{10.1002 / j q s .925}$

Benn DI, Gemmell AMD. 1997. Calculating equilibrium-line altitudes of former glaciers by the balance ratio method: a new computer spreadsheet. Glacial Geology and Geomorphology (http://ggg.qub.ac.uk/papers/full/1997/tn011997/tn01.html).

Benn DI, Lehmkuhl F. 2000. Mass balance and equilibrium-line altitudes of glaciers in highmountain environments. Quaternary International 65-66: 15-29. DOI: 10.1016/S1040$\underline{6182(99) 00034-8}$

Benn DI, Owen LA, Osmaston HA, Seltzer GO, Porter S, Mark B. 2005. Reconstructing equilibrium-line altitudes for tropical and sub-tropical glaciers. Quaternary International 138-139: 8-21. DOI: $\underline{10.1016 / j . q u a i n t .2005 .02 .003}$

Bigg GR, Clark CD, Hughes ALC. 2008. A last glacial ice sheet on the Pacific Russian coast and catastrophic change arising from coupled ice-volcanic interaction. Earth and Planetary Science Letters 265: 559-570. DOI: 10.1016/j.eps1.2007.10.052

Braithwaite RJ, Raper SCB. 2007. Glaciological conditions in seven contrasting regions estimated with the degree-day model. Annals of Glaciology 46: 296-302. DOI: $\underline{10.3189 / 172756407782871206}$ 
Braithwaite RJ, Raper SCB, Chutko K. 2006. Accumulation at the equilibrium line altitude of glaciers inferred from a degree-day model and tested against field observations. Annals of Glaciology 43: 329-334. DOI: $10.3189 / 172756406781812366$

Braitseva OA, Melekestsev IV. 1966. Age of contemporary reliefs in Kamchatka. In Problems of Kamchatka geography. Series IV. (In Russian)

Braitseva OA, Melekestsev IV, Evteeva IS, Lupikina EG. 1968. Stratigraphy of Quaternary Deposits and Glaciations of Kamchatka. Nauka Press: Moscow. (In Russian).

Braitseva OA, Melekestsev IV, Ponomareva VV, Sulerzhitsky LD. 1995. Ages of calderas, large explosive craters and active volcanoes in the Kuril-Kamchatka region, Russia. Bulletin of Volcanology 57: 383-402. DOI: 10.1007/BF00300984

Brugger KA. 2006. Late Pleistocene climate inferred from the reconstruction of the Taylor River glacier complex, southern Sawatch Range, Colorado. Geomorphology 75: 318-329. DOI: $\underline{10.1016 / j . g e o m o r p h .2005 .07 .020}$

Brigham-Grette J, Gualtieri LM, Glushkova OY, Hamilton DM, Kotov A. 2003. Chlorine-36 and ${ }^{14} \mathrm{C}$ chronology support a limited last glacial maximum across central Chukotka, northeastern Siberia, and no Beringian ice sheet. Quaternary Research 59: 386-398. DOI: $\underline{10.1016 / \mathrm{S} 0033-5894(03) 00058-9}$

Caissie BE, Brigham-Grette J, Lawrence KT, Herbert TD, Cook MS. 2010. Last Glacial Maximum to Holocene Sea Surface Condition at Umnak Plateau, Bering Sea as inferred from Diatom, Alkenone, and Stable Isotope Records, Paleoceanography 25. DOI: 10.1029/2008PA001671.

Cowton T, Hughes PD, Gibbard PL. 2009. Palaeoglaciation of Parque Natural Lago de Sanabria, northwest Spain. Geomorphology 108: 282-291. DOI: 10.1016/j.geomorph.2009.02.007 
Dahl SO, Nesje A. 1996. A new approach to calculating equilibrium-line altitudes and pinetree limits: a case study from, Hardangerjøkelen, central southern Norway. The Holocene 6 : 381-398. DOI: $10.1177 / 095968369600600401$

Erlich EN, Melekestsev IV, Tarakanovsky AA, Zubin MI. 1972. Quaternary Calderas of Kamchatka. Bulletin of Volcanology 36: 222-237. DOI: 10.1007/BF02596992

Fedotov SA, Zolotarskaya SB, Maguskin MA, Nikitenko YuP, Sharoglazova GA. 1988. The study of deformations of the Earth's surface on the Kamchatka Peninsula: Repeated Geodetic Measurements. Journal of Geodynamics 10: 175-188. DOI: 10.1016/0264-3707(88)90024-5

Felzer B. 2001. Climate impacts of an ice sheet in East Siberia during the Last Glacial Maximum. Quaternary Science Reviews 20: 437-447. DOI: 10.1016/S0277-3791(00)001062

Furbish DJ, Andrews JT. 1984. The use of hypsometry to indicate long term stability and response of valley glaciers to changes in mass transfer. Journal of Glaciology 30: 199-211.

Gasanov S. 1969. The structure and history of frozen rock formation in eastern Chukotka. Nauka: Moscow. (In Russian).

Glushkova OY. 1992. Paleogeography of Late Pleistocene Glaciation of North-Eastern Asia. Proceedings of the International Conference of Arctic Margins. Russian Academy of Sciences, Far East Branch. Northeast Science Center: Magadan.

Glushkova OY. 1996. Reflection of climatic rhythm in relief morphology of Western Beringia. In Quaternary Climates and Vegetation of Beringia, Bychkov YuM (ed.). NEISRI FEB RAS: Magadan; 94-114. (In Russian).

Glushkova OY. 2001. Geomorphological correlation of Late Pleistocene glacial complexes of Western and Eastern Beringia. Quaternary Science Reviews 20: 405-417. DOI: $\underline{10.1016 / \mathrm{S} 0277-3791(00) 00108-6}$ 
Glushkova OY, Sedov PV. 1984. Late Quaternary and modern glaciations of the Pekulnei Range. In Pleistocene Glaciation of Eastern Asia, Bespaly VG, Akhlamova AA (eds). NEISRI FESC AS of the USSR: Magadan; 131-140. (In Russian).

Golledge NR. 2007. An ice cap landsystem for palaeoglaciological reconstructions: characterizing the Younger Dryas in western Scotland. Quaternary Science Reviews 26: 213229. DOI: $10.1016 /$ j.quascirev.2006.08.007

Grosswald MG. 1988. An Antarctic-style ice sheet in the Northern Hemisphere: Toward the new global glacial theory. Polar Geography 12: 239-267. DOI: $\underline{10.1080 / 10889378809377369}$

Grosswald MG. 1998. Late-Weichselian ice sheets in Arctic and Pacific Siberia. Quaternary International 45/46: 3-18. DOI: 10.1016/S1040-6182(97)00002-5

Grosswald MG, Hughes TJ. 1999. The case for an ice shelf in the Pleistocene Arctic Ocean. Polar Geography 23: 23-54. DOI: $\underline{10.1080 / 10889379909377663}$

Grosswald MG, Hughes TJ. 2002. The Russian component of an Arctic Ice Sheet during the Last Glacial Maximum. Quaternary Science Reviews 21: 121-146. DOI: 10.1016/S0277$\underline{3791(01) 00078-6}$

Grosswald MG, Hughes TJ. 2004. Letter to the Editor. Quaternary Research 62: 223-226.

Grosswald MG, Kotlyakov VM. 1969. Present-day glaciers in the USSR and some data on their mass balance. Journal of Glaciology 8(52): 9-21

Gualtieri L, Glushkova O, Brigham-Grette J. 2000. Evidence for restricted ice extent during the last glacial maximum in the Koryak Mountains of Chutotka, far eastern Russia. Geological Society of America Bulletin 112: 1106-1118. DOI: $\underline{10.1130 / 0016-}$ 7606(2000)112<1106:EFRIED>2.0.CO;2 
Heiser PA, Roush JJ. 2001. Pleistocene glaciations in Chukotka, Russia: moraine mapping using satellite synthetic aperture radar (SAR) imagery. Quaternary Science Reviews 20, 393404. DOI: $10.1016 / \mathrm{S} 0277-3791(00) 00109-8$

Höfer H. 1879. Gletscher und Eiszeitstudien. Sitzungsberichte der Akadademie der Wissenschaften. Wien, Math.-Phys. Kl.I 79: 331-367.

Hughes PD. 2002. Loch Lomond Stadial glaciers in the Aran and Arenig Mountains, North Wales. Geological Journal 37: 9-15. DOI: 10.1002/gj.894

Hughes PD. 2009. Loch Lomond Stadial (Younger Dryas) glaciers and climate in Wales. Geological Journal 44: 375-391. DOI: 10.1002/gj.1153

Hughes PD, Braithwaite RJ. 2008. Application of a degree-day model to reconstruct Pleistocene glacial climates. Quaternary Research 69: 110-116. DOI: 10.1016/j.yqres.2007.10.008

Ivanov A. 2002. The Far East. In The Physical Geography of Northern Eurasia, Shahgedanova M (ed). Oxford University Press: Oxford; 422-447.

Kanasewitch ER. 1963. Gravity measurements on the Athabasca Glacier, Alberta, Canada. Journal of Glaciology 4: 617-631.

Kartashov IP. 1962. The origin of the Krasniy lake. Proceeding of AS of the USSR 142: 1111115. (In Russian).

Kaser G, Osmaston HA. 2002. Tropical glaciers. Cambridge University Press: Cambridge.

Koronovsky N. 2002. Tectonics and Geology. In The Physical Geography of Northern Eurasia, Shahgedanova M (ed). Oxford University Press: Oxford;1-35. 
Kovanen DJ, Slaymaker O. 2005. Fluctuations of the Deming Glacier and theoretical equilibrium line altitudes during the Later Pleistocene and early Holocene on Mount Baker, Washington, USA. Boreas 34: 157-175. DOI: $\underline{10.1080 / 03009480510012863}$

Kraevaya TS, Lupikina EG, Yegorova IA, Kuralenko NP, Sulerzhitskiy LD. 1983. On the age of the last Late Pleistocene glaciation of Kamchatka. Izvestiya AN SSSR, Series Geography 1: 90-94. (In Russian).

Kuhn M. 1989. The response of the equilibrium line to climate fluctuations: theory and observations. In Glacier fluctuations and climate change, Oerlemans J (ed). Kluwer: Dordrecht; 407-417.

Kuprina NP. 1970. Stratigraphy and History of Pleistocene Sedimentation in Central Kamchatka. Nauka: Moscow. (In Russian).

Lapshin LI. 1963. About the older glaciation of Kamchatka. Vopr. Geogr. Kamtschatki 1: 6264. (In Russian).

Laukhin SA. 1997. The Late Pleistocene glaciation in the northern Chukchi Peninsula. Quaternary International 41/42: 33-41. DOI: 10.1016/S1040-6182(96)00034-1

Laukhin SA, Zhimin J, Pushkar VS, Cherepanova MV. 2006. Last Glaciation in the Northern Part of the Eastern Chukchi Peninsula and Paleoceanography of the North Pacific. Doklady Earth Sciences 411A: 1422-1426. DOI: 10.1134/S1028334X06090194

Leonov VL, Kobrenkov DV. 2003. The Main Regularities in the Glacier Distribution of the Last Late Pleistocene Glaciation, Southeast Kamchatka. Bulletin of Kamchatka Regional Association Educational-Scientific Center: Earth Sciences 1. (in Russian).

Locke WW. 1995. Modelling of icecap glaciation of the northern Rocky Mountains of Montana. Geomorphology 14: 123-130. DOI: 10.1016/0169-555X(95)00053-5 
Lozhkin AV, Anderson PM, Matrosova TV, Minyuk PS. 2007. The pollen record from El'gygytgyn Lake: implications for vegetation and climate histories of northern Chukotka since the late middle Pleistocene. Journal of Paleolimnology 37: 135-153. DOI: $\underline{10.1007 / \mathrm{s} 10933-006-9018-5}$

Lydolph PE. 1977. Climates of the Soviet Union, World Survey of Climatology 7. Elsevier: Amsterdam.

Meier MF, Post AS. 1969. Recent variations in mass net budgets of glaciers in western North America. IASH 58: 63-77.

Meierding TC. 1982. Late Pleistocene Glacial Equilibrium-Line Altitudes in the Colorado Front Range: A Comparison of Methods. Quaternary Research 18: 289-310. DOI: $\underline{10.1016 / 0033-5894(82) 90076-X}$

Melekestsev IV, Braitseva OA. 1984. Giant collapses of volcanoes. Volcanology and Seismology 4: 14-23.

Mercer JH. 1961. The response of fjord glaciers to changes in the firn limit. Journal of Glaciology 3: 850-858.

Munroe JS, Mickelson DM. 2002. Last Glacial Maximum equilibrium line altitudes and paleoclimate, northern Uinta Mountains, Utah, U.S.A. Journal of Glaciology 48: 257-266. DOI: $\underline{10.3189 / 172756502781831331}$

Murray DR, Locke WW. 1989. Dynamics of the Late Pleistocene Big Timber Glacier, Crazy Mountains, Montana, USA. Journal of Glaciology 35: 183-190.

National Snow and Ice Data Center (NSIDC). 2009. World glacier inventory. World Glacier Monitoring Service and National Snow and Ice Data Center/World Data Center for Glaciology. Boulder, CO. Digital media.

Nesje A, Dahl SO. 2000. Glaciers and Environmental Change. Arnold: London. 
$\mathrm{Ng}$ FSL, Barr ID, Clark CD. in press. Using the surface profiles of modern ice masses to inform palaeo-glacier reconstructions. Quaternary Science Reviews. DOI: 10.1016/j.quascirev.2010.06.045

Nye JF. 1952. The Mechanics of glacier flow. Journal of Glaciology 2: 82-93.

Ohmura A, Kasser P, Funk M. 1992. Climate at the equilibrium line of glaciers. Journal of Glaciology 38: 397-411.

Olyunin VN. 1965. Ancient glaciation and recent volcanicity in Kamchatka. Izvestiya Academii Nauk USSR, Series Geography 1: 79-84. (In Russian).

Olyunin VN. 1966. Modern and historic glaciation of Kamchatka. Izvestiya Academii Nauk USSR, Series Geography 3: 70-78. (In Russian).

Ono Y, Aoki T, Hasegawa H, Dali L. 2005. Mountain glaciation in Japan and Taiwan at the global Last glacial Maximum. Quaternary International 138-139: 79-92. DOI: $\underline{10.1016 / \text { j.quaint.2005.02.007 }}$

Osipov EY. 2004. Equilibrium-line altitudes on reconstructed LGM glaciers of the northwest Barguzinsky Ridge, Northern Baikal, Russia. Palaeogeography, Palaeoclimatology, Palaeoecology 209: 219-226. DOI: 10.1016/j.palaeo.2004.02.021

Osmaston HA 1975. Models for the estimation of firnlines of present and Pleistocene glaciers. In Processes in Physical and Human Geography: Bristol Essays. Peel RF, Chisholm MDI, Haggett, P (eds).Heinemann: London; 218-245.

Osmaston H. 2005. Estimates of glacier equilibrium line altitudes by the Area $\times$ Altitude, the Area $\times$ Altitude Balance Ratio and the Area $\times$ Altitude Balance Index methods and their validation. Quaternary International 138-139: 22-31. DOI: 10.1016/j.quaint.2005.02.004 
Pedoja K, Bourgeois J, Pinegina T. 2004. Neotectonics ear the NW corner of the Pacific Plate: terraces on Ozernoi and Kamchatskiy Peninsulas, Kamchatka, Russia (Abstract). IV International Biennial Workshop on Subduction Processes Emphasizing the Japan-Kurile Kamchatka-Aleutian Arcs. Petropavlovsk-Kamchatsky, August 21-27, 2004.

Pedoja K, Bourgeois J, Pinegina T, Higman B. 2006. Does Kamchatka belong to North America? An extruding Okhotsk block suggested by coastal neotectonics of the Ozernoi Peninsula, Kamchatka, Russia. Geology 34 (5): 353-356. DOI: 10.1130/G22062.1

Pinegina TK, Bourgeois J. 2001. Historical and paleo-tsunami deposits on Kamchatka, Russia: long-term chronologies and long-distance correlations. Natural Hazards and Earth System Sciences 1: 177-185. DOI: 10.5194/nhess-1-177-2001

Porter SC. 1975. Equilibrium-line altitudes of Late Quaternary glaciers in the Southern Alps, New Zealand. Quaternary Research 5: 27-47. DOI: 10.1016/0033-5894(75)90047-2

Porter SC. 1977. Present and past glaciation threshold in the Cascade Range, Washington state, USE: constraints provided by palaeoenvironmental reconstructions. The Holocene 11: $607-611$.

Porter SC. 2001. Snowline depression in the tropics during the Last Glaciation. Quaternary Science Reviews 20: 1067-1091. DOI: 10.1016/S0277-3791(00)00178-5

Rea BR. 2009. Defining modern day Area-Altitude Balance Ratios (AABRs) and their use in glacier-climate reconstructions. Quaternary Science Reviews 28, 237-248. DOI: $\underline{10.1016 / j . q u a s c i r e v .2008 .10 .011}$

Rea BR, Evans DJA. 2007. Quantifying climate and glacier mass balance in north Norway during the Younger Dryas. Palaeogeography, Palaeoclimatology, Palaeoecology 246: 307330. DOI: $\underline{10.1016 / \text { j.palaeo.2006.10.010 }}$ 
Savoskul OS, Zech W. 1997. Holocene glacier advances in the Topolovaya valley, Bystrinskiy Range, Kamchatka, Russia dated by tephrochronology and lichenometry. Arctic and Alpine Research 29: 143-155. DOI: $\underline{10.2307 / 1552041}$

Schilling DH, Hollin JT. 1981. Numerical reconstructions of valley glaciers and small ice caps. In The Last Great Ice Sheets, Denton GH, Hughes TJ (eds). Wiley: New York; 207220.

Sergin SY, Scheglova MS. 1976. Beringia climate during ice ages as result of influence of global and local factors. Beringia in the Cenozoic. Nauka Press: Vladivostok. (In Russian).

Shahgedanova M, Perov V, Mudrov Y. 2002. The Mountains of Northern Russia. In The Physical Geography of Northern Eurasia, Shahgedanova M (ed). Oxford University Press: Oxford; 284-313.

Sissons JB. 1979. Palaeoclimatic inferences from former glaciers in Scotland and the Lake District. Nature 278: 518-521. DOI: $10.1038 / 278518 \mathrm{a} 0$

Smith CA, Lowell TV, Caffee MW. 2009. Lateglacial and Holocene cosmogenic surface exposure age glacial chronology and geomorphological evidence for the presence of coldbased glaciers at Nevado Sajama, Bolivia. Journal of Quaternary Science 24: 360-372. DOI: $\underline{10.1002 / \text { jqs. } 1239}$

Solomina O, Calkin P. 2003. Lichenometry as applied to moraines in Alaska, USA, and Kamchatka, Russia. Arctic, Antarctic, and Alpine Research 35: 129-143. DOI: 10.1657/1523-0430(2003)035[0129:LAATMI]2.0.CO;2

Stauch G, Gualtieri L. 2008. Late Quaternary glaciations in northeastern Russia. Journal of Quaternary Science 23: 545-558. DOI: 10.1002/jqs.1211

Stauch G, Lehmkuhl F, Frechen M. 2007. Luminescence chronology from the Verkhoyansk Mountains (North-Eastern Siberia). Quaternary Geochronology 2: 255-259. DOI: $\underline{10.1016 / \text { j.quageo.2006.05.013 }}$ 
Sutherland DG. 1984. Modern glacier characteristics as a basis for inferring former climates with particular reference to the Loch Lomond Stadial. Quaternary Science Reviews 3: 291309. DOI: $10.1016 / 0277-3791(84) 90010-6$

Velichko A, Spasskaya I. 2002. Climatic Change and the Development of Landscapes. In The Physical Geography of Northern Eurasia, Shahgedanova M (ed). Oxford University Press: Oxford; 36-69.

Velichko AA, Isayeva LL, Makeyev VM, Matishov GG, Faustova MA. 1984. Late Pleistocene Glaciation of the Arctic Shelf, and the Reconstruction of Eurasian Ice Sheets. In Late Quaternary Environments of the Soviet Union, Velichko AA (ed). Longman: London; $35-41$.

Vieira G. 2008. Combined numerical and geomorphological reconstruction of the Serra da Estrela plateau icefield, Portugal. Geomorphology 97: 190-207. DOI: 10.1016/j.geomorph.2007.02.042

Vlasov GM. 1964 (ed). Geology of USSR, vol. 31: Kamchatka, Kuril and Komandor islands. Nedra: Moscow. (In Russian).

Vtyurin BI, Svitoch AA. 1978. Recent Deposits and Paleogeography of Western Kamchatka. Nauka Press: Moscow. (In Russian).

World Glacier Monitoring Service (WGMS). 2008. Fluctuations of Glaciers 2000-2005, Volume IX, Haeberli W, Zemp M, Kääb A, Paul F, Hoelzle M (eds). World Glacier Monitoring Service: Zurich.

World Meteorological Organisation (WMO). 1998. World Meteorological Organisation, 1961-1990 global climate normals, Electronic Resource. National Climatic Data Center: US, Asheville, NC. CD-ROM. 
Yanase W, Abe-Ouchi A. 2007. The LGM surface climate and atmospheric circulation over East Asia and the North Pacific in the PMIP2 coupled simulations. Climate of the Past 3: 439-451. DOI: $10.5194 / \mathrm{cp}-3-439-2007$

Yokoyama Y, De Deckker P, Lambeck K, Johnston P, Fifield KL. 2001. Sea-level at the Last Glacial Maximum: evidence from northwestern Australia to constrain ice volumes for oxygen isotope stage 2. Palaeogeography, Palaeoclimatology, Palaeoecology 165: 281-297. DOI: $\underline{10.1016 / \mathrm{S} 0031-0182(00) 00164-4}$

Zamoruyev V. 2004. Quaternary glaciation of north-eastern Asia. In: Quaternary Glaciations - Extent and Chronology, Part III: South America, Asia, Africa, Australia, Antarctica, Ehlers J, Gibbard PL (eds). Elsevier: Amsterdam; 321-323. DOI: 10.1016/S1571-0866(04)80137-4

Zech W, Bäumler R, Savoskul OS, Braitseva OA, Melekestsev IV. 1997. Evidence of Middle Pleistocene glaciation in SW-Kamchatka. Zeitschrift für Gletscherkunde und Glazialgeologie 33: $15-20$. 


\section{Figures}

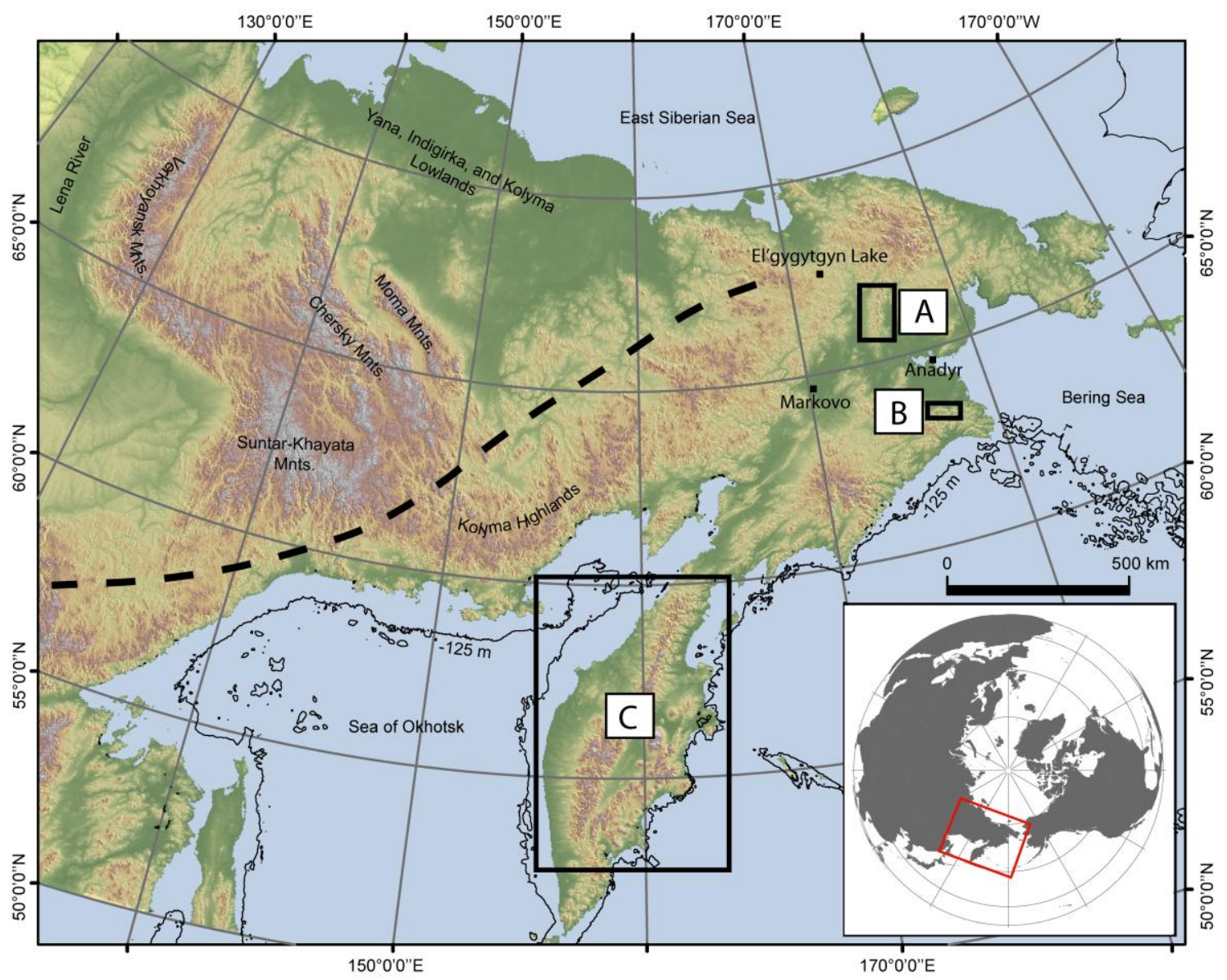

\section{Figure 1}

Key topographic regions of Far NE Russia. The dashed black line represents a rough division between Pacific (to the east) and non-Pacific (to the west) sectors (based upon Grosswald and Kotlyakov, 1969). Boxed regions (A), (B) and (C) are the Pekulney, Kankaren and Sredinny Mountains, respectively, and are the focus of this study. Also shown is the gLGM shoreline, given a $125 \mathrm{~m}$ lowering of sea level relative to present. 


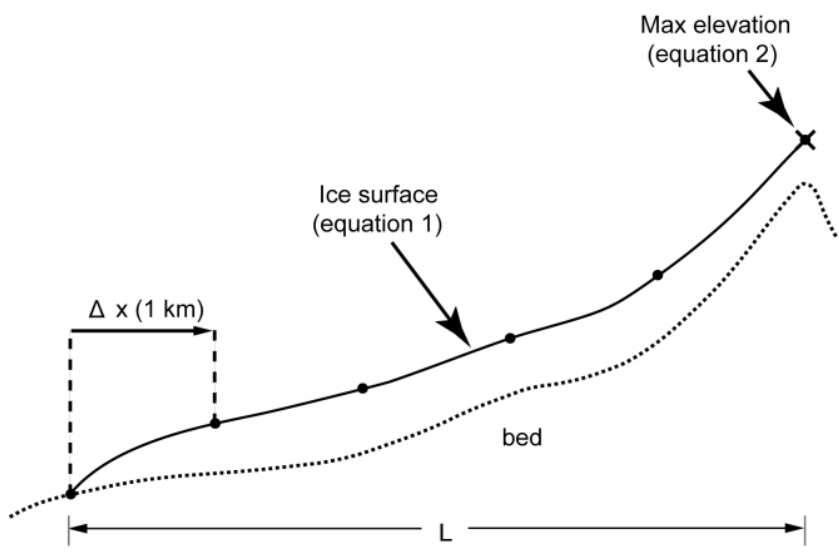

Figure 2

Schematic illustration of a reconstructed ice-mass surface profile, viewed in cross-section. The surface is generated using an iterative flowline model (equation 1), where bed elevations are extracted at $1 \mathrm{~km}$ intervals $(\Delta \mathrm{x}=1 \mathrm{~km})$, along an inferred flowline (flowline length $=\mathrm{L}$ ). The maximum ice surface elevation at the upper-end of the profile is determined by equation 2, which corresponds to a 'typical' surface for modern ice-masses of this span (L) (see Barr, 2009; Ng et al., 2010). 


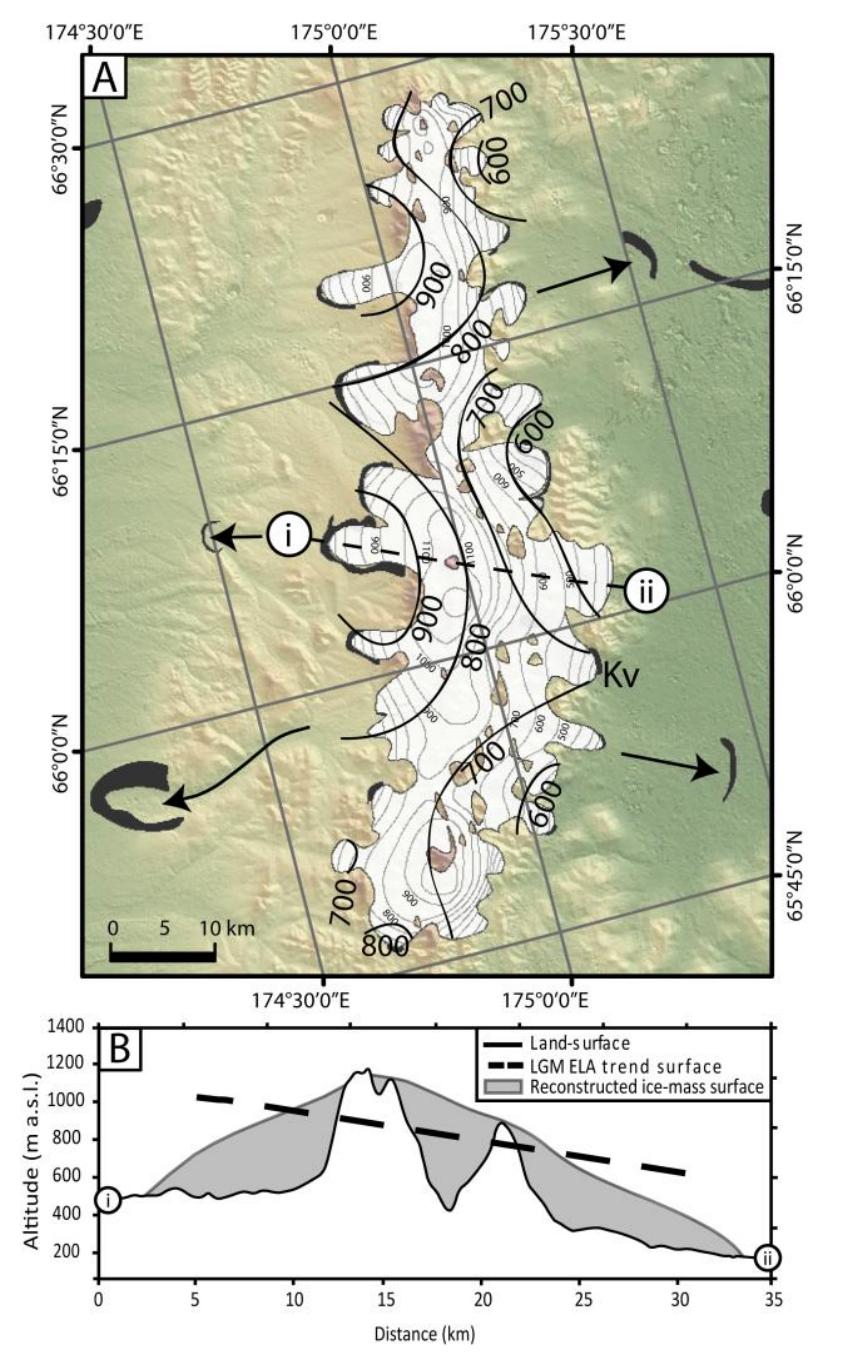

\section{Figure 3}

(A) Reconstruction of the Pekulney Ice Field during the gLGM. The ice surface contour interval is $100 \mathrm{~m}$. Also shown is a third-order polynomial trend surface, contoured at $100 \mathrm{~m}$ intervals, depicting ELA (BR $=1.8)$ across the Mountains during the gLGM. End moraines are mapped as black polygons, and black arrows indicate inferred ice flow directions during some pre-gLGM phase of advance. The outlet marked ' $\mathrm{Kv}$ ' occupies the Kuveveem valley, where moraines have been chronologically constrained to the gLGM (see Brigham-Grette et al., 2003). Land surface topography is shaded ASTER GDEM data. Ice surface-area and volume are $970 \mathrm{~km}^{2}$ and $241 \mathrm{~km}^{3}$, respectively. (B) Topographic profile, from ' $\mathrm{i}$ ' to 'ii', across the Pekulney Mountains, showing the land surface, the gLGM ELA trend surface, and the reconstructed ice surface ( $7.5 x$ vertical exaggeration). The trend surface clearly indicates an increase in ELA from east to west, potentially reflecting a palaeo-precipitation gradient. Modern ELA (or snowline) in this region is virtually unknown, and estimates cannot be included here. 

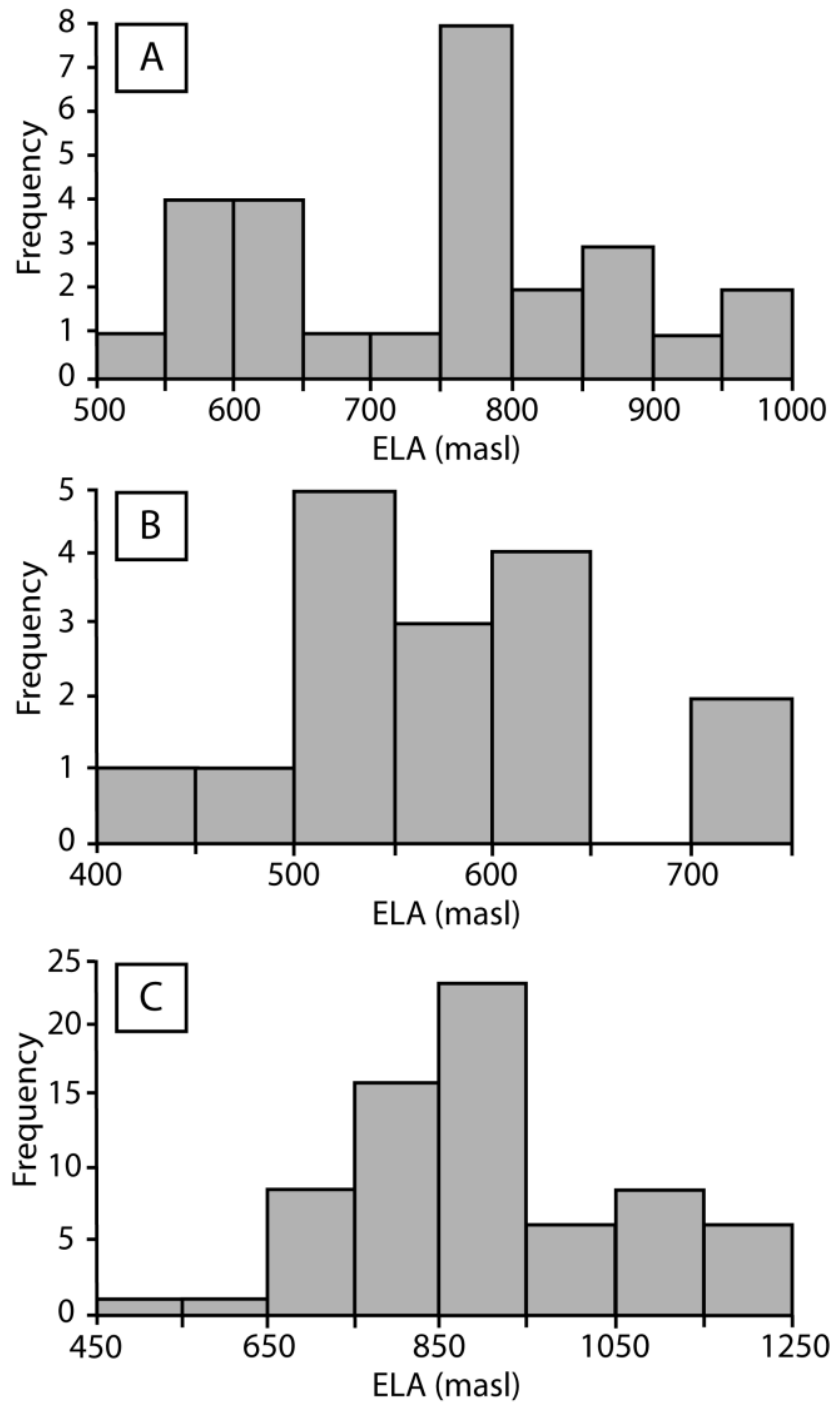

Figure 4

Histogram of gLGM ELA estimates (based on a BR of 1.8) for individual outlets of (A) the Pekulney Ice Field, (B) in the Kankaren Mountains, and (C) the Sredinny Ice Field 


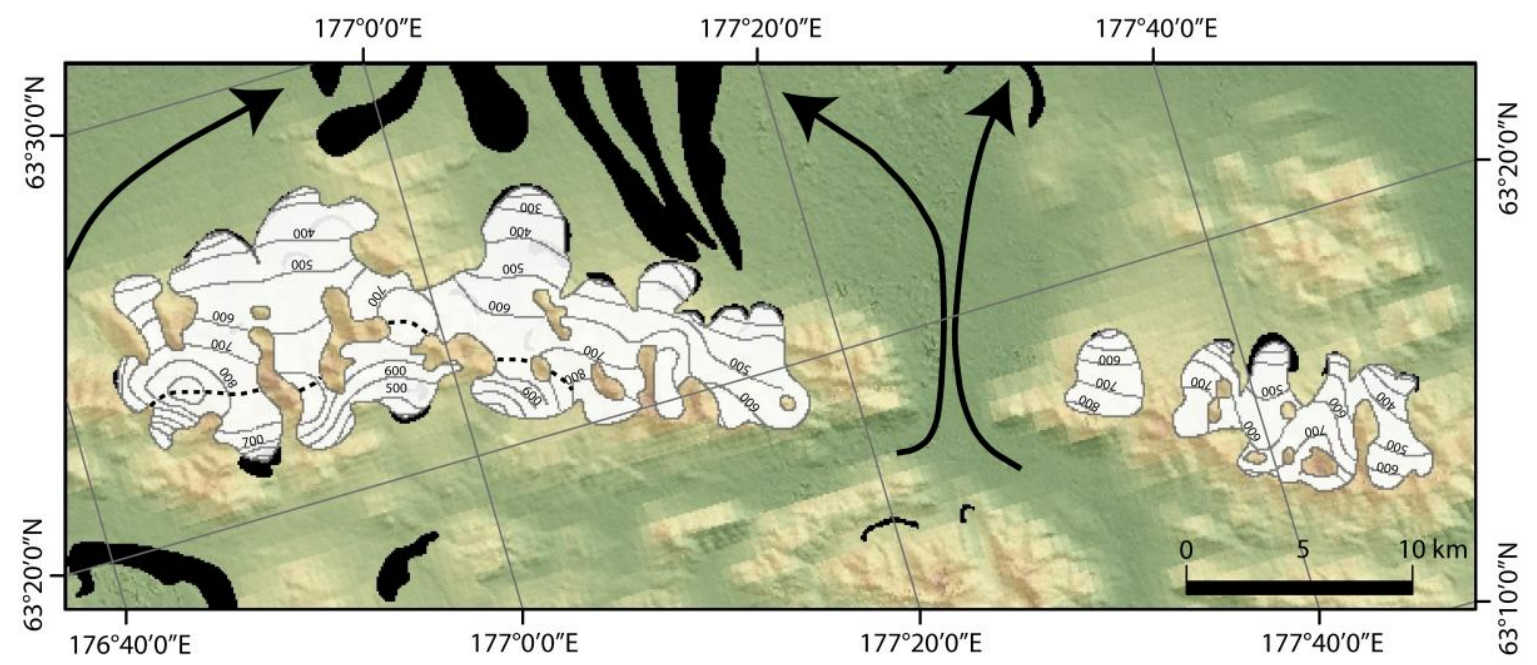

\section{Figure 5}

Reconstruction of gLGM glaciers in the Kankaren Mountains. The ice surface contour interval is $100 \mathrm{~m}$, and the dashed line indicates the division between northern and southern sectors. Also shown are end moraines (black), and indicators of inferred ice flow directions during some pre-gLGM phase of advance (black arrows). Land surface topography is shaded ASTER GDEM data. Ice surface-area and volume are $215 \mathrm{~km}^{2}$ and $31 \mathrm{~km}^{3}$, respectively. 

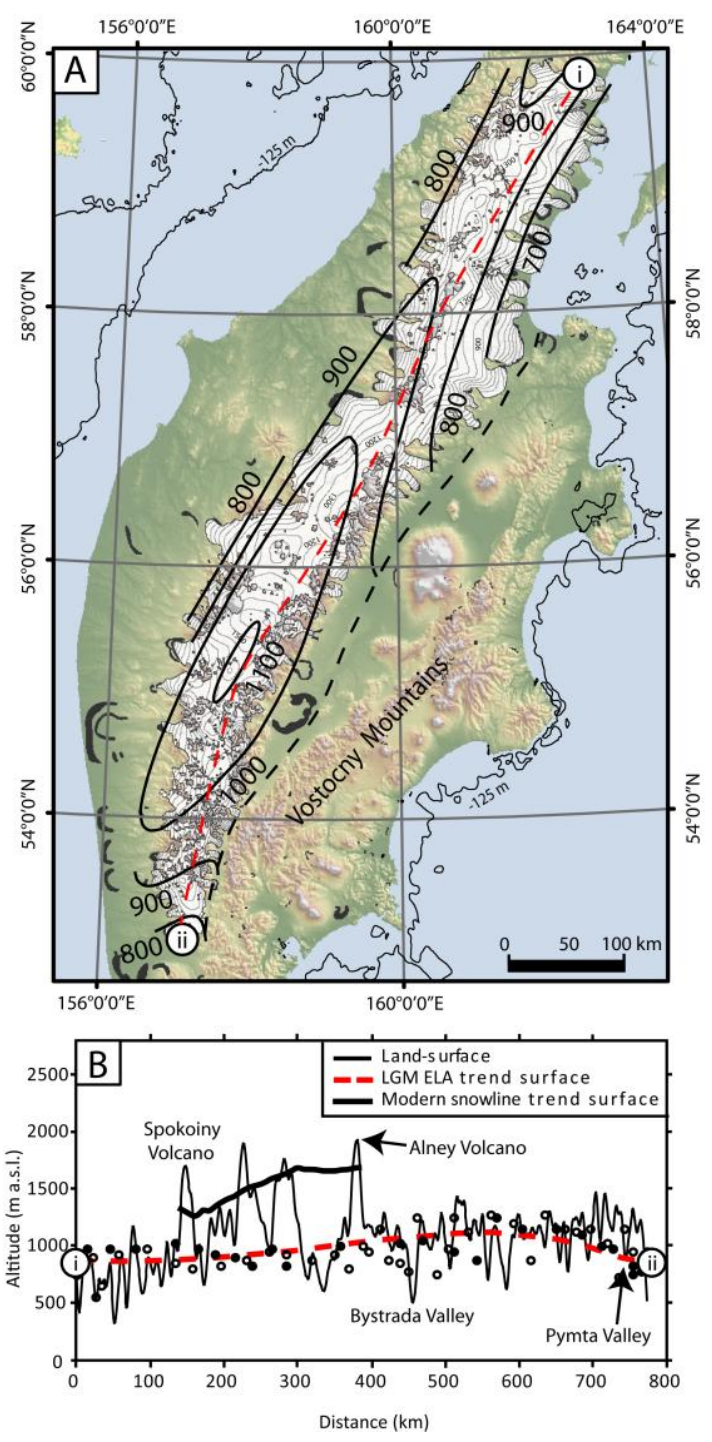

Figure 6

(A) Reconstruction of the Sredinny Ice Field during the gLGM. The ice surface contour interval is $100 \mathrm{~m}$. Also shown is a third-order polynomial trend surface, contoured at $100 \mathrm{~m}$ intervals, depicting ELA $(B R=1.8)$ across the Mountains during the gLGM. End moraines are mapped as black polygons. Land surface topography is shaded SRTM DEM data. Ice surface-area and volume are $57,363 \mathrm{~km}^{2}$ and $22,147 \mathrm{~km}^{3}$, respectively. The dashed line, to the east of the Sredinny Mountains, delimits the area where ice was reconstructed. Also shown is the gLGM shoreline, given a $125 \mathrm{~m}$ lowering of sea level relative to present. (B) Topographic profile, from 'i' to 'ii', along the Sredinny Mountains (following the dashed line), showing the land surface topography, the gLGM ELA trend surface, individual gLGM ELA estimates for individual outlets to the west (filled dots) and east (hollow dots) of the Sredinny Ice field, and a trend surface depicting modern snowline altitudes from NSIDC (2009) (150x vertical exaggeration). 
Table 1. Equilibrium-line altitudes (ELAs) of reconstructed gLGM ice masses in the Pekulney, Kankaren and Sredinny Mountains.

\begin{tabular}{llllll}
\hline Ice mass & ELA 1 $(\mathrm{m})$ & ELA 2 $(\mathrm{m})$ & ELA 3 $(\mathrm{m})$ & ELA 4 (m) & ELA 5 (m) \\
& AAR =0.5 & AAR =0.6 & BR =1.67 & BR =1.8 & BR = 2.0 \\
\hline Pekulney Ice Field & 784 & 738 & 747 & 744 & 739 \\
Kankaren ice masses & 599 & 558 & 579 & 575 & 571 \\
Sredinny Ice Field & 966 & 888 & 905 & 898 & 887 \\
\hline
\end{tabular}

All ELA estimates are measured in metres above modern sea level. 